\title{
Aspects of Geophysical Exploration for Groundwater Using Vertical Electrical Sounding (VES) in Parts of University of Benin, Benin City, Edo State *11MOUKHUEDE M. IDEHAI; AYIBAWARI O. EGAI
}

\author{
Department Of Geology, University Of Benin, Benin City, Nigeria
}

\author{
KEYWORDS: Vertical Electrical Sounding (VES), Hydrogeological Parameters, Aquifer
}

\begin{abstract}
A geophysical survey using vertical electrical sounding (VES) was undertaken within the University of Benin (Ugbowo Campus) in an attempt to ascertain aspects of the hydrogeological parameters for groundwater exploitation. Six (6) vertical electrical soundings with electrode spacing of $215 \mathrm{~m} \mathrm{AB} / 2$ were occupied along the traverse, with the aid of ABEM SAS 1000 Terrameter set. The data were interpreted using the IXID and 3-D field-

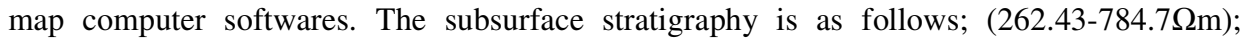

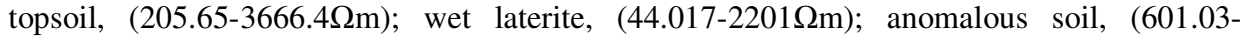

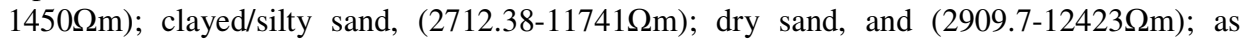
aquifer. The results reveal depth to water table ranges of $31.2-65.5 \mathrm{~m}$. The range of values of minimum thickness of the aquifer across the VES is from $45-63 \mathrm{~m}$. VES 3 is the shallowest and may be the cheapest to drill and install a borehole. VES 6 with a inferred depth of 63$65.5 \mathrm{~m}$, will probably be the best area to site a borehole in spite of the expected cost imperatives. The area shows slight spatial variations and plausibly attests to natural inhomogeneity, anthropogenic interplay in the course of the development of the area via construction, and very marginal susceptibility to contamination from the health centre and hostels within the study area. Furthermore, the results conformed to those of previous writers who described the aquifer as sandy and highly prolific. () JASEM
\end{abstract}

http://dx.doi.org/10.4314/jasem.v18i1.3

Introduction:

Earth masses have electrical properties. The electrical resistivity of different geological materials is a function of a number of factors, which include variations in water contents, dissolved ions in water and material make-up. Resistivity investigations can thus be used to identify zones with different electrical properties. The Schlumberger resistivity method has over the years proved useful in delineation of groundwater and aquifer characteristics due to its better depth interpretation. Previous investigators such as Van Overmeeren, (1989), McNeil, (1990), and Atakpo and Akpoborie, (2008), have buttressed this. However, it is possible for different rock types to have the same range of resistivity (Ezomo, and Akujieze, 2010), this usually make electrical resistivity data ambiguous to interpret. The operational efficiency of six points per decade in subsurface geophysical study in groundwater exploration has been documented arising from theoretical approach to electrical resistivity (Ezomo, 2010). Electrical resistivity methods involve the measurement of the apparent resistivity. Given expansion and population growth in the university, there is the need to proactively map outs areas of optimal groundwater supply for exploitation. This forms the main thrust of this investigation, which attempts to delineate the appropriate aquifer area with a view to producing a blueprint to siting high yield boreholes in the area in view of its concomitant benefits.

Description of the Study Area: The area of investigation lies within longitude $5.62^{\circ} \mathrm{E}$ and latitude $6.4^{0} \mathrm{~N}$ approximately $350 \mathrm{~km} \mathrm{SW}$ of Abuja. University of Benin has a human population of over 40,000 . The Ugbowo Campus in Benin City of Edo State lies within the tropical rain forest and has two distinct seasons (wet; April to October, and dry; November to March). The study area lies within the Benin Formation (Fig 1-3) which extends from the west across the whole of the Niger Delta area and southward beyond the present coastline. It consists of over $90 \%$ sandstone with shale intercalations. It is coarse grained, gravelly, locally fine grained, poorly sorted, sub-angular to well- rounded and bears lignite streaks and wood fragment. It is a continental deposit of probably upper deltaic depositional environment. Various structural units (point bars, channels fills, natural levees, back swamp deposit, ox-bow fills) are identifiable within the formation, indicating a 
variability of the shallow water depositional medium. In the subsurface, it is of Oligocene age in the north and becoming progressively younger southward. In general, it ranges from Miocene to Recent. The thickness is variable but generally exceeds $2 \mathrm{Km}$. In terms of hydrogeological potentials; Offodile, (2002) described the Benin Formation as the most aquiferous formation in Southern Nigeria. It has transmissivity of $\quad 880-30,000 \mathrm{M}^{2} /$ day $\quad 1.53-3.16 \times 10^{-3}$-storage coefficient average porosity is $30 \%$. Akujieze, (2004) investigated the Benin Formation and reported unconfined to semi confined aquifers in certain places. Etu-Efeotor, and Akpokodje, (1990), identified three major aquifers therein.

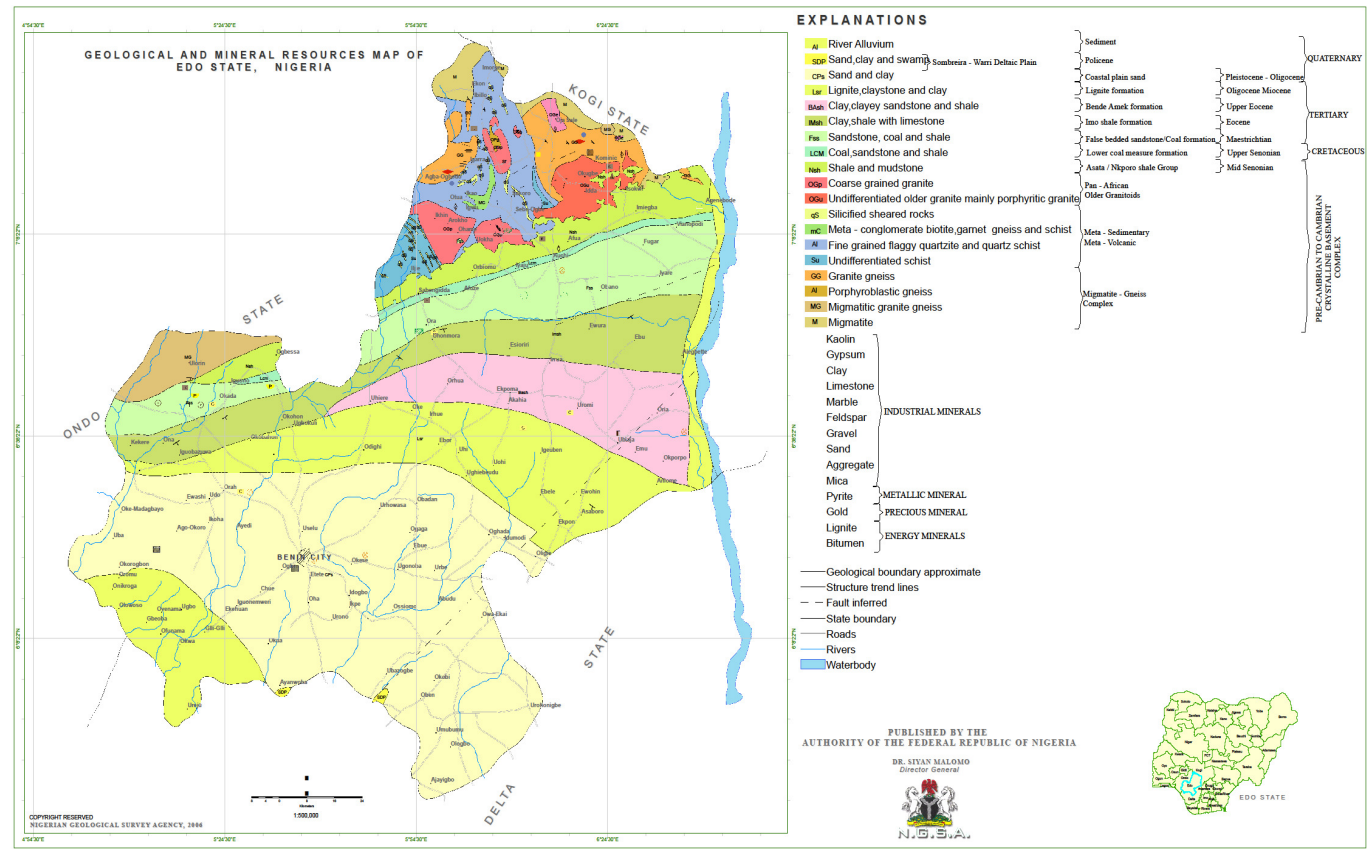

Fig.1: Geological Map of Edo State Showing Benin City and other Locations (Nigerian Geological Survey Agency, 2006)

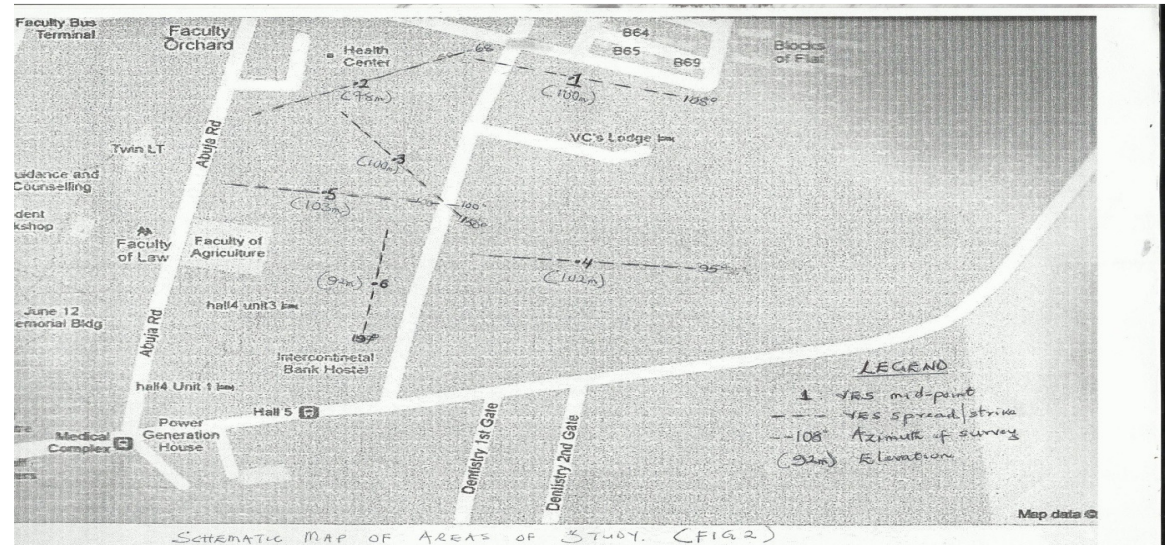

Fig 2; Schematic Map of the Study Area. 


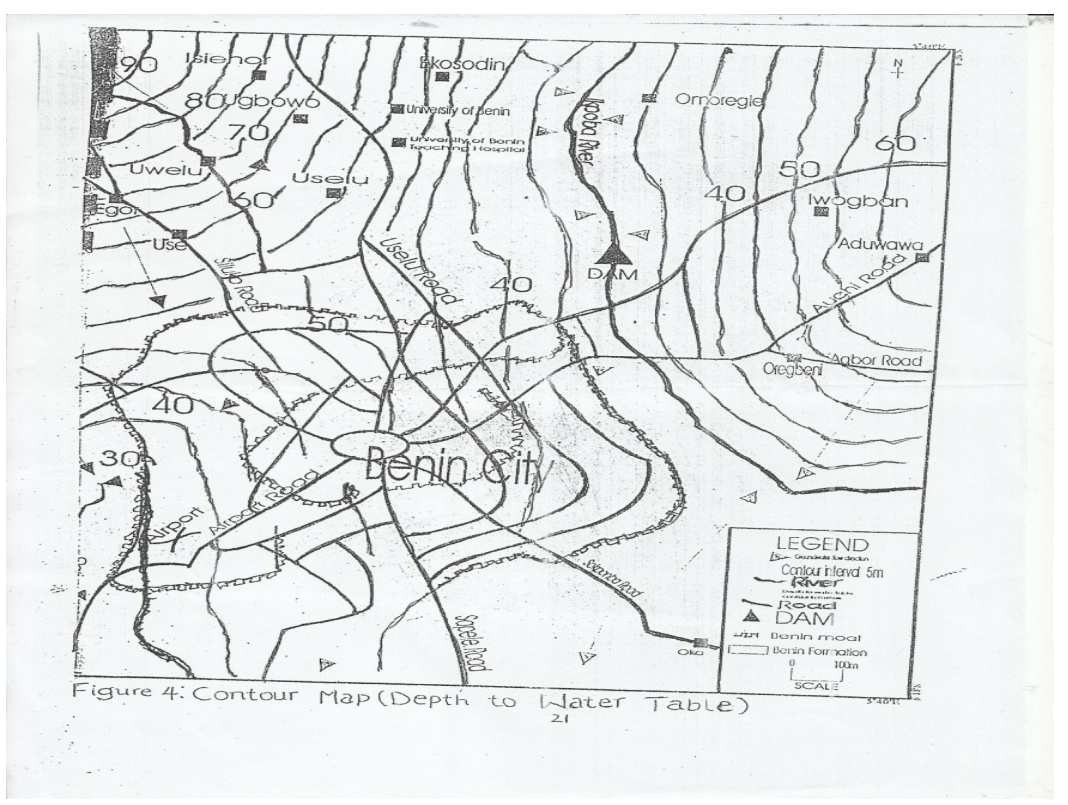

Fig 3; Groundwater Depth to Water Table Map of Benin City (From Edo State Water Board)

Methodology: Six (6) VES points were acquired. Data were generated at six points per decades which covered 215 meters of $\mathrm{AB} / 2$ and 430 metres of $\mathrm{AB}$. The Schlumberger array method was employed in the study. The potential electrodes remained fixed at a point while the current electrodes were expanded symmetrically about the centre of the spread. The potential electrodes were also increased when the current electrode were too far apart (in other to maintain a measurable potential). The inner potential electrodes were maintained to have spacing, which is small compared to that of the outer current electrodes $(\mathrm{AB} / 2)$.

Measurement were made by introducing an artificially generated electric current into the

ground through two electrodes $(\mathrm{AB})$ and the resulting voltage differences (potential drop)

across the other two potential electrodes (MN) were taken.

The ABEM SAS1000 Terrameter) was used for electrical measurements. It is designed so that the ratio of the potential drop to the measured current is read directly as resistivity in ohms $(\Omega)$ or milli ohms
(MS) after a minimum average of two cycles or maximum average of four cycles. The values obtained are the resistivity of all earth materials to the depth that is proportional to the electrode spacing. Apparent resistivity is defined as the resistivity of an electrically homogeneous and isotropic half-space that would yield the measured relationship between the applied current and the potential difference for a particular arrangement and spacing of electrodes.

\section{RESULTS AND DISCUSSION}

Table 1: VES 1 results and interpretation.

\begin{tabular}{llllll}
\hline $\begin{array}{l}\text { Apparent } \\
\text { Resistivity }\end{array}$ & Thickness & Depth & Elevation & Inferred lithology & $\begin{array}{l}\text { Curve } \\
\text { Type }\end{array}$ \\
\hline $\mathbf{2 6 2 . 4 3}$ & 0.57741 & 0.57741 & 99.423 & top soil & QHAQ \\
& & & & & \\
$\mathbf{2 0 5 . 6 5}$ & 2.7185 & 3.2959 & 96.704 & wet laterite & \\
$\mathbf{4 4 . 0 1 7}$ & 3.3174 & 6.6133 & 93.387 & anomalous soil & \\
$\mathbf{6 0 1 . 0 3}$ & 2.8527 & 9.466 & 90.534 & clayey soil & \\
$\mathbf{3 0 6 1 . 4}$ & 4.4239 & 13.89 & 86.11 & silty sand & \\
$\mathbf{2 9 2 3 8}$ & 31.322 & 45.211 & 54.789 & dry sand & \\
$\mathbf{2 9 0 9 . 7}$ & 47.193 & 92.405 & 7.5952 & aquifer & \\
$\mathbf{3 9 3 . 2 4}$ & & & & & \\
\hline
\end{tabular}

Table 2: VES 2 results and interpretation

\begin{tabular}{llllll}
\hline $\begin{array}{l}\text { Apparent } \\
\text { Resistivity }\end{array}$ & Thickness & Depth & Elevation & Inferred lithology & Curve Type \\
\hline $\mathbf{4 0 0 . 7 8}$ & 0.35401 & 0.35401 & 77.646 & top soil & AQHAK \\
$\mathbf{1 1 3 4 . 8}$ & 0.93292 & 1.2869 & 76.713 & wet laterite & \\
$\mathbf{4 2 5 . 8 1}$ & 1.1152 & 2.4021 & 75.598 & clayey soil & \\
$\mathbf{7 5 9 . 8 2}$ & 3.3851 & 5.7872 & 72.213 & laterite & \\
$\mathbf{3 9 9 4 . 6}$ & 10.756 & 16.543 & 61.457 & silty sand & \\
$\mathbf{1 2 9 8 5}$ & 17.854 & 34.397 & 43.603 & dry sand & \\
$\mathbf{1 4 1 0 . 8}$ & 45.712 & 80.108 & -2.1082 & aquifer & \\
$\mathbf{7 3 7 . 3 5}$ & & & & & \\
\hline
\end{tabular}


Table 3: VES 3 results and interpretation

\begin{tabular}{llllll}
\hline $\begin{array}{l}\text { Apparent } \\
\text { Resistivity }\end{array}$ & Thickness & Depth & Elevation & Inferred lithology & Curve Type \\
\hline $\mathbf{6 3 5 . 6}$ & 0.29159 & 0.29159 & 99.708 & top soil & AKQHAK \\
$\mathbf{4 7 5 7 . 3}$ & 0.64201 & 0.93359 & 99.066 & soaked soil & \\
$\mathbf{9 6 8 . 9 8}$ & 2.05 & 2.9836 & 97.016 & clayey soil & \\
$\mathbf{1 2 2 0 . 1}$ & 4.5422 & 7.5258 & 92.474 & laterite & \\
& & & & & \\
$\mathbf{1 1 7 2 . 3}$ & 6.9165 & 14.442 & 85.558 & silty sand & \\
$\mathbf{2 4 8 9 3}$ & 16.716 & 31.158 & 68.842 & dry sand & \\
$\mathbf{1 2 4 2 3}$ & 28.616 & 59.774 & 40.226 & aquifer & \\
\hline
\end{tabular}

Table 4: VES 4 results and interpretation

\begin{tabular}{llllll}
\hline Apparent Resistivity & Thickness & Depth & Elevation & Inferred lithology & Curve Type \\
\hline $\mathbf{7 8 4 . 7 9}$ & 0.43396 & 0.43396 & 101.57 & moist top soil & AKQHAKQ \\
$\mathbf{3 6 6 6 . 4}$ & 1.0394 & 1.4733 & 100.53 & saturated sub soil & \\
$\mathbf{2 2 0 1}$ & 2.3191 & 3.7924 & 98.208 & laterite & \\
$\mathbf{1 4 5 0}$ & 5.0052 & 8.7976 & 93.202 & clayey soil & \\
$\mathbf{1 9 6 5 . 5}$ & 7.6536 & 16.451 & 85.549 & silty sand & \\
$\mathbf{1 1 7 4 1}$ & 31.709 & 48.16 & 53.84 & dry sand & \\
$\mathbf{3 4 3 6 . 4}$ & 25.985 & 74.145 & 27.855 & aquifer & \\
$\mathbf{1 2 9 8 . 3}$ & 98.361 & 172.51 & -70.507 & silty sand & \\
$\mathbf{1 6 0 2 . 2}$ & & & & & \\
\hline
\end{tabular}

Table 5: VES 5 results and interpretation

\begin{tabular}{llllll}
\hline $\begin{array}{l}\text { Apparent } \\
\text { Resistivity }\end{array}$ & Thickness & Depth & Elevation & Inferred lithology & Curve Type \\
\hline $\mathbf{7 5 0 . 9 2}$ & 0.60056 & 0.6006 & 102.4 & saturated sub soil & QHAKQHAKQ \\
$\mathbf{3 3 2 . 6 9}$ & 0.95453 & 1.5551 & 101.44 & laterite & \\
$\mathbf{2 7 9 8 . 4}$ & 2.1375 & 3.6926 & 99.307 & clayey soil & \\
$\mathbf{4 7 0 . 5 7}$ & 4.5254 & 8.218 & 94.782 & silty sand & \\
$\mathbf{9 9 0 . 0 4}$ & 6.418 & 14.636 & 88.364 & dry sand \\
$\mathbf{3 6 6 5 . 3}$ & 32.979 & 47.615 & 55.385 & aquifer & \\
$\mathbf{6 4 7 . 4 3}$ & 71.863 & 119.48 & -16.477 & silty sand & \\
$\mathbf{9 4 9 . 6}$ & & & & & \\
\hline
\end{tabular}

Table 6: VES 6 results and interpretation

\begin{tabular}{llllll}
\hline $\begin{array}{l}\text { Apparent } \\
\text { Resistivity }\end{array}$ & Thickness & Depth & Elevation & Inferred lithology & Curve Type \\
\hline $\mathbf{8 0 5 . 3 2}$ & 0.7756 & 0.7756 & 91.224 & saturated sub soil & AKQHAK \\
$\mathbf{1 4 5 3 . 4}$ & 1.29 & 2.0656 & 89.934 & laterite & \\
$\mathbf{5 7 8 . 3}$ & 2.1761 & 4.2417 & 87.758 & clayey soil & \\
$\mathbf{1 2 1 1 . 8}$ & 3.6069 & 7.8486 & 84.151 & silty sand & \\
$\mathbf{1 7 4 4 . 7}$ & 15.323 & 23.171 & 68.829 & dry sand & \\
$\mathbf{9 3 4 9}$ & 42.312 & 65.483 & 26.517 & aquifer & \\
$\mathbf{2 2 6 8 . 1}$ & 62.721 & 128.2 & -36.204 & silty sand & \\
& & & & & \\
\hline
\end{tabular}

The interpretation of the sounding curves is based on the assumption that the subsurface consists of a sequence of distinct layers of finite thickness. Each layer is assumed horizontal and electrically homogeneous and isotropic. However, in actuality, this is not always so. Unknown in the field, VES1 breached some precautionary measures. This section seems to have buried pipelines (reflected by changes in flow paths due to the high conductivity of metals), plausible topographical variations- from construction/ trenching (distort potential field), and possession of anisotropic material (a joint set in bedrock filled with water can cause electrical current to have a preferred path). 


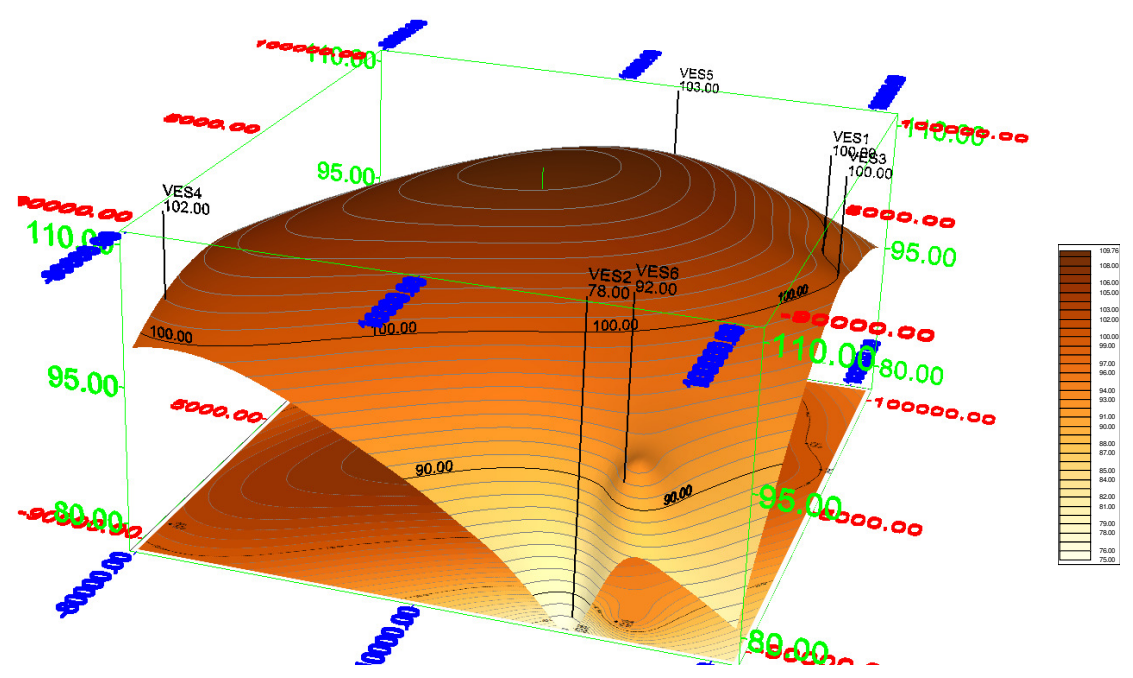

Fig 4: Schematic 3-D representation of the topography of the study area. (A comparison with the 3-D view of the saturated water level (fig 5) reveals striking similarities and seems to suggest that the groundwater flow is structural controlled in the study area).

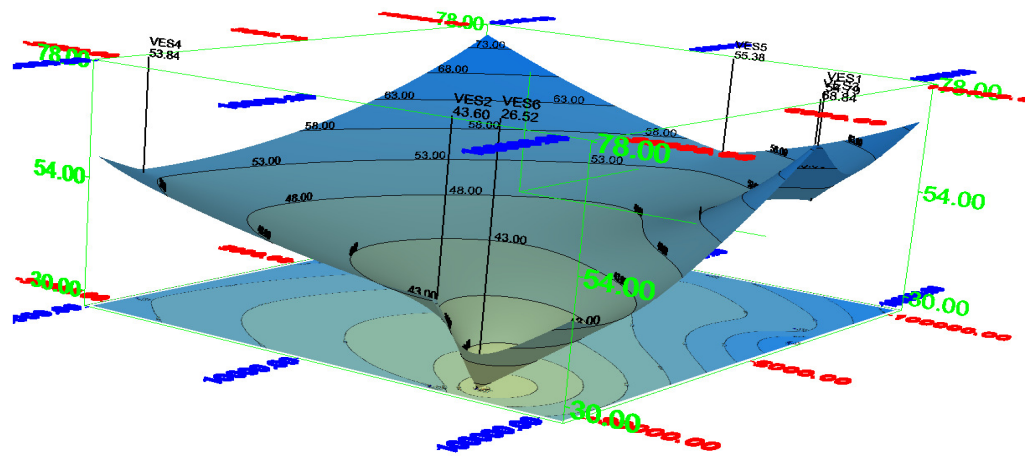

Fig. 5: 3-D view of the saturated water level of the study area showing VES points

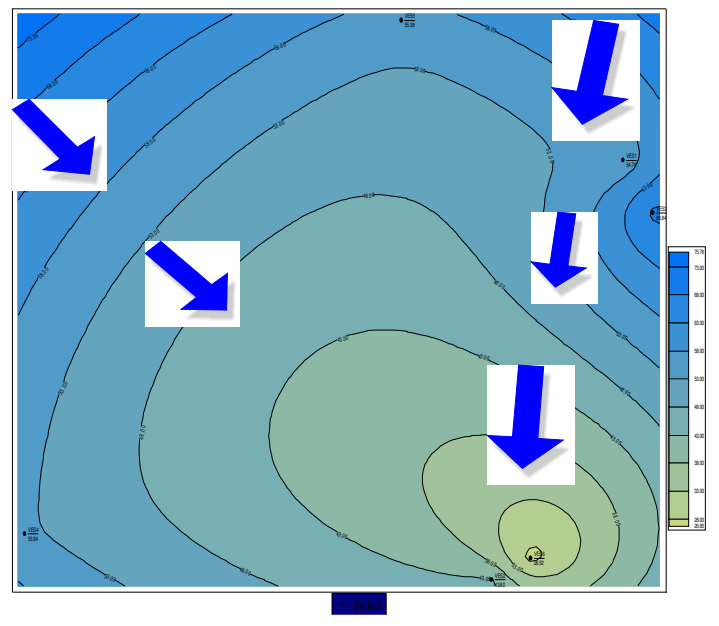

Fig.6: Apparent flow direction of groundwater

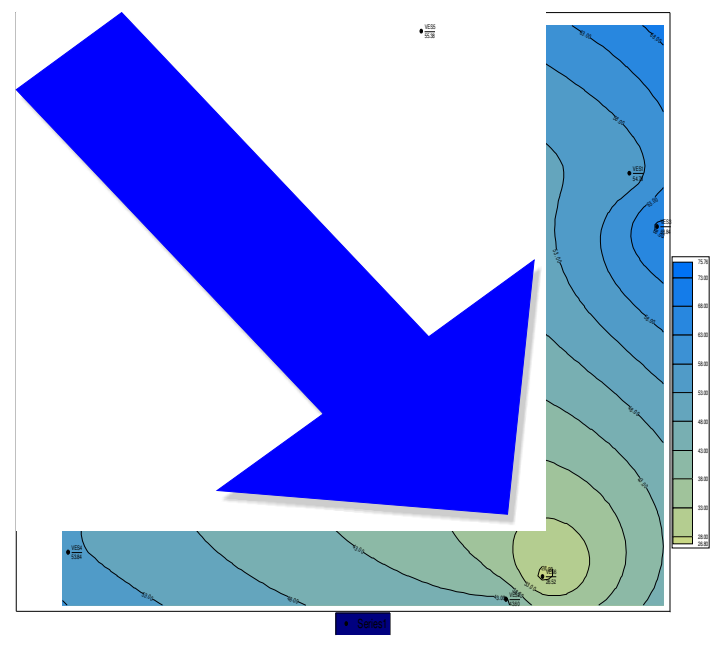

Fig. 7: True flow direction of groundwater flow. (estimated using the 3-D software and a 3-point solution) 
Despite the series of adjustment and computation iteration, it became obvious that the resistance of an additional point had to be included for the entire survey to be sufficiently meaningful. Albeit, combining a mix of physics and geomathematics this was achieved. Thus: The ratios of the adjacent resistance at the potential spacing of $10 \mathrm{~m}$ were evaluated. (ie, 1.03/0.84 $=1.2261$, $0.84 / 0.58=1.448, \quad 0.58 / 0.27=2.1481$,) Using extended equivalence, it was found by approximation to be 0.1 . Thus: If 1.2261 $=100 \%$, then $1.448=118 \%, 2.1481=175$. Hence the difference in per cent: $118-100$ $=18,175-118=57$. The difference $(57-18) \%$ $=39 \%$. This is equivalent percent for the next point. That is, $175+39=214$. Therefore, $0.27 / *=214$. Hence, $*=0.1 \Omega$. This is the resistance sought. The Geometric factor (GF) can be calculated using: $\mathrm{GF}=\{[$ $(\mathrm{AB} / 2) 2-(\mathrm{MN} / 2) 2] /(\mathrm{MN} / 2)\} \pi / 2$. (Where the designations take their regular meanings). Substituting, GF=14,123.29. The apparent resistivity is given by the product of the GF and the resistance to be $1,412.32$ $\Omega \mathrm{m}$.

Computer iteration techniques were employed by using IXID and 3-D field map software to exhibit models of the lithologies. Resistivity of soils and rocks is also a function of depth or position. Typically, resistivity of geologic material and of near surface material is heavily affected by groundwater which is a low resistivity material. In general, finer grained sediments have low resistivity, and bedrock has high resistivity (table 1-6). Resistivity is reduced by: increasing porosity, increasing ion content of groundwater, increasing content of clay, decreasing grain size, etc. Apparent resistivity was from about $400 \Omega \mathrm{m}$ to about $24,000 \Omega \mathrm{m}$. The anomalous values obtained in VES 1 are considered to be resultant from interference. Seemingly, against the norm, which stipulate that soundings be taken across suspected underground cables to attenuate its effects, this particular VES was inadvertently applied parallel to the interfering medium. It however produced very interesting outcomes that may be the subject of future research work. For instance, it also revealed that metal/ cables were buried up to a depth of about $3.3 \mathrm{~m}$ in a lateritic horizon below the surface. Again, it is highly plausible that certain other metals were buried at a depth of $6.61 \mathrm{~m}$ near the Vice- Chancellor's lodge. The effect of tunnelling also seems contributory to this anomaly.

The saturated water level (SWL) values hover from 26.3-68.8m with a mean of approximately $50.5 \mathrm{~m}$. The depth to the aquifer is between $31.2-65.5 \mathrm{~m}$. The lower limit of $65.5 \mathrm{~m}$ correlates more with the established depth for this area of the Benin Formation (Fig. 2).The inferred lithologies are laterites, clay, silty sand, dry sand. The aquifer inundates the sandy formation. These were deduced from the sounding curves and profiling. The observed sounding curves for the six locations show that of $\mathrm{H}$ - type (Table 1-6) $(\rho 1>\rho 2<\rho 3), \mathrm{KA}-$ type $(\rho$ $1<\rho 2>\rho 3<\rho 4), \mathrm{HQ}-$ type $(\rho 1>\rho 2<\rho 3>$ $\rho 4), \mathrm{HA}$ - type $(\rho 1>\rho 2<\rho 3<\rho 4)$ and A type $(\rho 1<\rho 2<\rho 3)$, etc.

The entire area is suitable for borehole siting for water abstraction. Nonetheless, it may add value to double-check geophysical results here with well-logging analysis of actual boreholes. Depth to water table ranges from $31.2-65.5 \mathrm{~m}$. These depth values are expected to be higher in the dry seasons and in periods of significant abstraction. VES 3 area is the shallowest and may be the cheapest to drill and install a borehole. However, for the purposes of long-term and large-scale abstraction, and assuming this borehole is to be operated simultaneously with other boreholes, the best area to site a borehole will be the VES 6 area. But, it is the deepest at $65.5 \mathrm{~m}$-with attendant cost imperatives. The average minimum thicknesses of the aquifer are from $45-63 \mathrm{~m}$. The thickness at VES 6 is about $63 \mathrm{~m}$.

To optimise the use of the entire aquifer, it is good practice to drill just below the aquifer. While the entire aquifer area is screened, the 
limiting area just below the aquifer is not screened but should be used for reinforcement of the borehole casing structure. The impermeable area below the aquifer is often made of clay/ shale. Screening this area will clog the borehole at worst or introduce colloidal materials to the borehole at the least. A comparison with the 3 -D view of the saturated water level (fig $4 \& 5)$ reveals striking similarities and seems to suggest that the groundwater flow is structurally controlled in the study area). Corollary, from the preponderance of deductions from the data acquired and processed, it was possible to estimate the true direction of groundwater flow (Fig. 6 \& 7 ) and this reinforces the veracity of the claim of the use of VES 6 as the best borehole siting area in this study. Overall, the results did not reflect significant concerns for groundwater contamination.

Conclusion: The aquifer in the study area seems prolific. All VES areas are suitable for drilling, nonetheless; VES 6 area holds the best hydrogeological parameters for water borehole siting and should be the least susceptible to the impact of groundwater variations in terms of abstraction and recharge. The true groundwater flow direction takes a clue from topography, depth and thicknesses of the inferred clayey lithology. The resistivity values combined with reconnaissance survey seems to suggest the negligible role of contaminants in the environment. However, to ascertain the authenticity of this inference, further work will be required.

Acknowledgement: The authors are highly indebted to Messrs. Sikiru I. Salami and Muyiwa, and staff of the Department of Geology, University of Benin for their immense assistance all through the course of this work.

\section{REFERENCES}

ABEM manual, ABEM Instrument AB, http://www.abem.com

Akujieze C .N. (2004). Effects of Anthropogenic Activities (Sand Quarrying and Waste Disposal) on Benin City Urban Groundwater System and Aquifer Vulnerability Assessment in Edo State Nigeria Ph.D. Thesis, University Of Benin, Benin City, Nigeria

Atakpo E. A. \& Akpoborie A. I. (2008). Geoelectric mapping of Amukpe area of Delta State, Nigeria Journal of Science Environment, 7; 73-82

Etu-Efeotor J.O. \& Akpokodje E.G. (1990). Aquifer systems of the Niger Delta. Journal of Mining and Geology, 26, 279-294

Ezomo F. O. \& Akujieze C. N. (2010). Geophysical study of the aquifer attributes at Agbor Area of Delta State. Journal of Science, Engineering and Technology. 17 (3), 9617-9625

Ezomo F. O. (2010). Journal of the Nigerian association of maths and physics vol 17(1), 403-408

MCNeil J. D (1990). Use of

electromagnetic methods for groundwater studies, in ward, SH, Ed, geotechnical and environmental geophysics (1) society of exploration geophysics 191-218

Nigerian Geological Survey Agency, (2006). Geological and Mineral Resource Map of Edo State

Offodile, M.E. (2002). Groundwater Study and Development in Nigeria. $2^{\text {nd }}$ edition. Mecon Geology, Ltd, Jos 453p

Van Overmeeren R. A. (1989). Aquifer boundaries explored by geoelectric measurement in the coastal plain of Yamen. A case equivalence. Journal of Geophysics vol 54; 39-48 